\title{
Crop Microclimate Modification to Address Climate Change
}

\author{
Udit Debangshi
}

${ }^{1}$ B.Sc. student, Institute of Agriculture, Visva-Bharati, Sriniketan-731236, West Bengal, India

\begin{abstract}
Climate-related agricultural vulnerabilities, as well as their implications for food security and farm livelihoods, have been extensively documented. Extreme weather events such as floods, droughts, heat and cold waves, hailstorms, strong winds, cyclones, and other weather events have increased the exposures of agriculture to climate risk. These processes are hampered by a lack of appropriate climatic elements, resulting in an unfavourable drop in crop productivity. Increased frequency and intensity of droughts and floods, as well as erratic precipitation patterns are predicted to increase year-to-year yield variability in crop production. Microclimate, which refers to the climatic elements in the immediate vicinity of the plants, is critical because it regulates and affects the physiological reactions of the plants as well as the energy exchange activities between the plant and its surroundings. Implementation of such microclimatic modifications in crop production are required to manage extreme weather risks and boost crop output in order to increase food security and agricultural sustainability in this changing climate. The goal of this paper is to improve crop production and land productivity by modifying microclimate as a manifestation of the efficiency and effectiveness of growth factor utilisation.
\end{abstract}

Key words: Agriculture's vulnerability, Crop productivity, Climate change, Microclimatic modifications.

\section{INTRODUCTION}

Agriculture is an indispensable sector of the Indian economy since it produces a large portion of our food, including crops, animals. Farmers always prefer a production system with less variation in yield over the year but the increased frequency of extreme weather events as a result of global warming has resulted in a significant increase in agricultural vulnerability and climatic risks. Climate change and agriculture are inextricably linked, and both occur on a global scale. Climate change has an especially negative impact on agriculture. Climate change poses a variety of challenges including temperature, $\mathrm{CO}_{2}$, and rainfall, which affect plant development directly and indirectly through land availability, irrigation, weed growth, insect and disease outbreaks, and so on. The global average temperature has risen at a pace of $1.7^{\circ} \mathrm{C}$ per century since $1970^{[28]}$. Heat waves, also known as extreme temperature occurrences, are expected to grow more intense, frequent, and longer than they do now ${ }^{[29]}$. Due to the vagaries of the hazards, the climatic potential yield, which is based mostly on climatic conditions, is diminished. Drought reduces the quality of fodder available to livestock for grazing. The use of fossil fuels, industrial activities, deforestation, and agriculture are all major contributors to climate change. Carbon dioxide accounts for $76 \%$ of all greenhouse gas emissions, followed by methane (16\%), nitrous oxides (6\%), and chlorofluorocarbons (2\%) ${ }^{[15]}$. Methane emissions from rice fields, enteric fermentation in ruminant animals, and nitrous oxides from manure and fertiliser application to the soil account for $28 \%$ of India's greenhouse gas emissions ${ }^{[3]}$. By 2100, global circulation models forecast a 
$1.5^{\circ} \mathrm{C}$ increase in world average temperature. Similarly, by the end of the twenty-first century, atmospheric $\mathrm{CO}_{2}$ concentrations are expected to rise from 478 ppm ${ }^{[16]}$. Snow cover is projected to decrease in increased temperature conditions, and the frequency and intensity of extreme weather events such as heat and cold waves, intense rainfall events, and so on are likely to increase. Global warming has resulted in increased heavy precipitation and decreased light precipitation in many places of the world ${ }^{[36]}$. Plants are forced to mature as a result of terminal heat stress, resulting in a reduction in crop yield. In general, increased $\mathrm{CO}_{2}$ levels promote vegetative growth, but the reproductive stage of the crop is more closely linked to an optimum temperature, so the economic yield is reduced as the temperature rises because it does not reach the critical temperature at the critical stages, and increased vegetative growth caused by elevated $\mathrm{CO}_{2}$ quickly depletes all-residual soil moisture, reducing the economic yield. Short-term crop failures and long-term production let-downs are more likely as precipitation patterns change. Erratic rainfall with high $\mathrm{CV} \%$ lead to erosion loss and waterlogged situation.

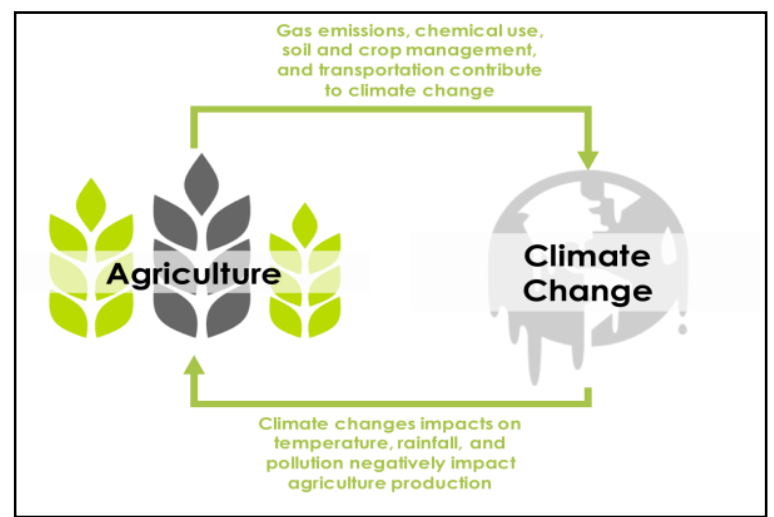

Figure 1: Climate change and agriculture are intimately linked (source:https://digital.hbs.edu/platform-rctom/wp-

content/uploads/sites/4/2017/11/ag-climate-768x586.png )

Microclimate modification refers to any artificially caused changes in the composition, behaviour, or dynamics of the atmosphere near the ground in order to improve the environment in which crops are grown. Any cultivar's optimal performance is determined by its genetic potential as well as the favourable environmental conditions to which it has been exposed. Microclimate manipulation has the ability to provide the greatest possible environment for crop plants. We can change the agricultural microclimate without spending a lot of money by making simple changes/ adjustments in crop management. By making such changes, the microclimate can be improved and allow more crop development and output ${ }^{[27]}$. A future trend in agrometeorological study is artificial management of plant environment to maintain optimum conditions for enhanced plant growth and crop output. Microclimate modification techniques can be useful adaptive strategies in agriculture for managing extreme weather sensitivity and climatic risks. Farm-level changes and protected cultivation improve crop development and yield performance by modifying the physical environment, sun radiation, soil temperature, soil moisture, and wind speed, among other factors. Mulching aids in the regulation of soil temperature and the conservation of soil moisture by limiting evaporation losses, therefore protecting the crop from adverse weather conditions. For the most efficient use of solar energy, Plant density and spatial arrangement can be modified. Wind breaks play an important role in reducing the wind. Improved irrigation management and a modified crop micro-environment result in increased heat and water consumption efficiency. As a result, microclimatic modification plays a significant role in climate change management.

\section{MICROCLIMATE MODIFICATION}

Crop microclimate refers to the climate just above and within the crop canopy and in the soil root zone that can be influenced by day-to-day management practices at various time scales ${ }^{[37]}$. It refers to any climatic condition that exists within a few metres or less above and below the Earth's surface, and within vegetation canopies. The best crop microclimate is one that provides the most favourable 
environment for the desired plant response, that is, the response that maximizes crop productivity. The phrase is most commonly used to describe the surfaces of terrestrial habitats, but it can also be used to describe the surfaces of oceans and other bodies of water. Microclimate modification is an attempt to change or regulate the elements of climate on a micro scale, resulting in a climate that is favourable for plant growth. Temperature, humidity, wind and turbulence, dew, frost, heat balance, and evaporation all influence microclimatic conditions. Key plant responses to microclimate can be managed for either radiation budgets, heat balances and moisture balances ${ }^{[38]}$. Microclimates are greatly influenced by soil type. Sandy soils, as well as other coarse, loose, and dry soils, are vulnerable to extremes in surface temperature, with high maximum and low minimum temperatures. Vegetation is also important because it regulates the amount of water vapour released into the atmosphere through transpiration [6]. Furthermore, vegetation has the capacity to insulate the soil beneath it and reduce temperature variability. Microclimates regulate precipitation and control evaporation and transpiration from surfaces, making them crucial to the hydrologic cycle-that is, the mechanisms involved in the circulation of the Earth's waters.

\section{MICROCLIMATIC COMPONENTS}

Microclimates are the dynamic, localised interactions between various processes in the surface layer, such as energy and matter exchange, radiation processes, and underlying surface effects. [12]

\section{Soil moisture and microclimate}

One of the most important microclimate determinants is soil moisture. When soil moisture is present, the thermal conductivity and heat capacity of the soil are considerably boosted ${ }^{[4]}$. As a result, soil moisture-rich locations have a more balanced microclimate with lower air and soil temperatures. This not only helps plants develop, but it also has an impact on weather and local rainfall patterns. There has been a lot of research in the last decade on the link between a lack of soil moisture and the incidence of severe temperatures and heat waves, both locally and regionally [41]. Soil biotic life can thrive when there is enough moisture in the soil. Microorganisms help soil fertility by breaking down organic materials and releasing nutrients. When moisture occupies roughly $60 \%$ of the available soil moisture, optimal conditions are achieved. An abundance of water obstructs the delivery of oxygen, causing microbial activity to stall, cease, or turn anaerobic, negatively impacting plant growth ${ }^{[5]}$.

\section{Soil characteristics and microclimate}

The relative amounts of clay, silt, and sand particles in the soil affect the texture. Clay particles are the tiniest, have the biggest surface area, and have the greatest ability to absorb water. Sand has the biggest particles and the least ability to absorb water. As a result, sandy soils have a lower moisture availability and a faster evaporation rate than clay soils. Clay soils, on the other hand, can harden in droughtprone locations, reducing infiltration and increasing runoff, reducing water availability. The soil structure is made up of soil texture, soil organic matter, and biological activity on the surface and below ground. The structure has to do with the development of micro- and macroaggregates, which are the ways that distinct particles are held together. A good structure can reduce the wind and water erosion, as well as induce water infiltration and storage.

\section{Soil temperature and microclimate}

Incoming radiation, as well as the soil's thermal conductivity and heat capacity, determine the temperature of the soil. Soil colour has an impact on how much incoming radiation is absorbed or reflected. Darker soil absorbs a greater percentage of solar energy, whereas lighter soils reflect sunlight and are colder. During the day, heat transfer into the soil moves heat away from 
the direct surface, resulting in lower temperatures. When the surface temperature drops at night, the soil's heat transfer direction reverses, and heat is released to the surface, bringing the extremes back into balance. Over longer time scales, the same process happens, with heat being stored during warmer months and released during cooler months ${ }^{[4]}$. The temperature of the soil promotes crop growth by supplying the warmth required by seeds, plant roots, and soil microorganisms. Plant growth can be hampered by high soil temperatures, while excessive temperatures can halt microorganism biological processes ${ }^{[9]}$. Low soil temperatures, on the other hand, impede plant water intake, hinder nitrification, diminishing soil fertility, and exacerbate desiccation when air temperatures are greater ${ }^{[14]}$. High and low soil temperatures both affect plant evapotranspiration by increasing or lowering it.

\section{Air temperature and microclimate}

The most important factor of local air temperature is incoming and outgoing radiation. Local vegetation can promote transpiration, which lowers the temperature. Vegetation can also provide shade, preventing radiation from reaching lowerlying plants or surface levels (partially). Using the cooling effect of soil moisture to reduce total air temperature can result in higher crop yields by reducing extreme temperatures. The reflectivity of a surface determines how much sunlight is absorbed, which is referred to as albedo. It has a significant impact on determining local air temperatures, and it changes greatly depending on the weather. Local location has a significant impact on incoming radiation such as the direction in which a slope faces, influences the amount of energy received as well as shade. The albedo of the soil is determined by its moisture content. Because precipitation changes the local albedo and provides moisture for evaporation, the interaction between rainfall and air temperature is significant. A dry soil has a higher albedo than a wet soil in general. Croplands have a higher albedo than forests, which means they reflect more sunlight back into the sky and produce less surface heat ${ }^{[20]}$. Surface processes and qualities interact with temperature, moisture, and wind. Through shade, vegetation alters the radiation balance while also acting as a wind barrier ${ }^{[14]}$. The upper crown has the highest air temperature, which happens one to two hours after local noon ${ }^{[12]}$. Daytime temperatures are lower below the crown. The cooling of the earth's surface and the air near the ground, known as radiation cooling, causes minimum temperatures in the upper crown at night. This is especially true when the sky is clear, the wind is quiet, and the humidity is low.

\section{Air humidity and microclimate}

High humid air absorbs water vapour more slowly than dry air, thus reduce plant transpiration. The existence of local wind is necessary to mix the environment since it moves damp air away from the vegetation ${ }^{[31]}$. Dew formation was shown to be aided by mild breezes in unsheltered areas, but dew formation was found to be inhibited by moderate to high winds ${ }^{[33]}$. Dew production and duration are influenced by the presence of vegetation that acts as a windbreak or offers shade. Windbreaks can help generate dew by reducing wind speeds, but they can also minimise it because local warmer air layers are not eliminated. Vegetation provides shade, which serves to lower local surface temperatures, increasing the odds of dew formation ${ }^{[2]}$. The ability of wind to move air humidity can have a substantial impact on local humidity levels, both increasing and decreasing.

\section{Wind and microclimate}

Wind has the ability to cool plants by removing the warm air-boundary layer that surrounds them. The removal of the layer and replacement with unsaturated air, causes higher transpiration, may also alter the plant's water intake. Furthermore, air circulation in the vegetation canopy is necessary for maintaining good $\mathrm{CO}_{2}$ levels 
for growth, removing excess humidity, and lowering the general humidity level, minimising the risk of illness. Depending on the ambient temperature, wind can make temperatures warmer or cooler ${ }^{[4]}$. In addition, many cereal crops are pollinated by the wind. Bacteria and fungi, like pollinators, rely on wind to move to new hosts, while insects use wind to expand their range ${ }^{[14]}$. Dew formation is also influenced by local winds. Sediments carried by the wind collided with plant leaves and stems, causing structural damage. wind have a cascading effect on the microclimate through the modification of vegetation potential and soil moisture storage capacity [32]

\section{MAJOR FIELD MICROCLIMATE MODIFICATIONS TECHNIQUES}

Extreme weather conditions exist above and below ideal weather condition. Climate change is projected to amplify the frequency, intensity, and consequences of certain types of extreme weather events. These variables affect the development and growth of the plants. Rainfall/moisture, temperature, solar radiation, evaporation and evapotranspiration, and wind are all important meteorological characteristics. If one of those features is out of the box, the growth of the crop will suffer. Excessive rainfall, for example, causes floods, whereas a lack of rainfall causes drought. Cold wave conditions will occur if the temperature is significantly below normal. On the other hand, if the temperature is significantly higher than normal, a heat wave may occur. Similarly, cyclones have a negative impact on crop growth. Weather hazards are a significant threat to both crops and human activities. As a result, weather hazards must be modified using a variety of techniques in order to reduce losses.

\section{Modification of water balance and temperature through Mulch application}

In the recent past, due to climate change, some areas have experienced severe drought, flooding, and other weather-related issues. On the other hand, scientists believe that relatively wet areas, such as the tropics and higher latitudes, will become wetter, while relatively dry areas, such as the subtropics (home to the majority of the world's deserts), will become drier. These vulnerabilities can be reduced by using mulch (organic or plastic). In a variety of ways, residue mulch left on or applied to the soil alters the crop microclimate above and below the soil surface, as well as within the mulch. Farmers all across the world use a variety of strategies, including residue retention, mulch application, and/or live mulch planting to modify solar radiation, reflection and absorption, shade, thermal radiation, temperature, humidity, wind/air movement, evaporation (crop and soil), soil moisture (surface and inside), and crop composition, structure, and growth. It may be beneficial to the seedbed because it prevents water loss from the soil surface, but heavy coatings may impede the germination of seeds that are sensitive to light and temperature variations. Depending on the properties of the residues, simultaneous changes in soil moisture and temperature, and changes in plant physiological activities as a result of the environmental circumstances provided by mulches. Mulch helps to store moisture, decrease the temperature of the soil, inhibit weed development, and promote fertility and soil health. Because of reduced soil evaporation and increased plant transpiration, mulching with crop leftovers boosted water-use efficiency by 20-30\%. Straw mulching has been observed to boost water use efficiency from 1.72 to $1.94 \mathrm{~kg} \mathrm{~m}^{-}$ 3 in winter wheat ${ }^{[8]}$. In drought situation using supplemental irrigation with mulch during the grain-filling stage resulted in a higher grain yield and can modify the microclimate ${ }^{[47]}$. Mulch reduces the amount of solar energy that reaches the soil surface. During the winter, they raise the soil temperature, and during the summer, they lower it. During the summer, white and light-coloured materials with high reflectivity are used to lower soil 
temperature, whereas dark-coloured materials and black plastic mulches are used to raise soil temperature during the winter. Mulches reduce the rate of evaporation from the soil and conserve soil moisture for use by the plants by obstructing the exchange of water vapours. The benefits are greater during the summer / kharif season and on low-retentivity soils. Under mulch, potato had a much greater leaf area index, absorbed photosynthetically active radiation, yield, and water usage efficiency, which they believe is attributable to soil moisture conservation and a $4-6^{\circ} \mathrm{C}$ reduction in soil temperature ${ }^{[22]}$. Mulch functions as a physical barrier to exchange processes on the soil's surface, altering the roughness of the soil/atmosphere boundary layer as well as the surface layer's dynamical heat and moisture properties ${ }^{[35]}$. This straw layer is an excellent example of microclimate management and manipulation, both historically and more recently.

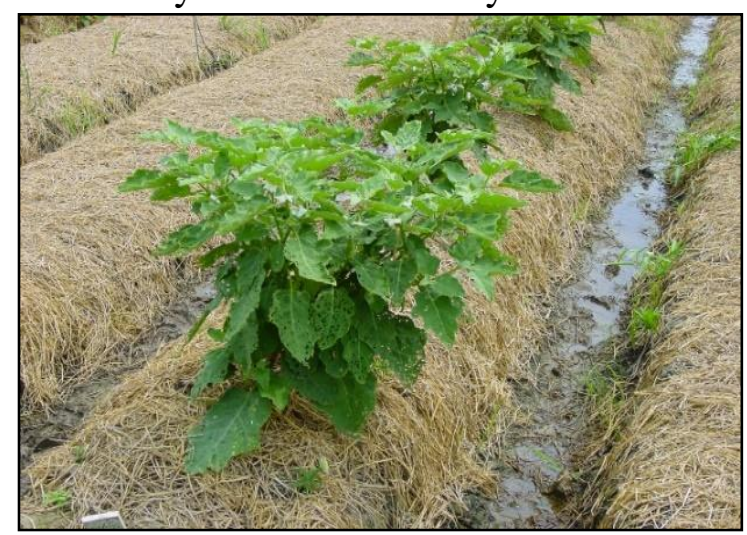

Figure 2: Organic mulches used in crop production ( source:https://www.google.com/url?sa=i\&url=https $\% 3 A \% 2 F \% 2$ Fipm-info.org )

\section{Modification of solar interception through Plant density and spatial arrangement}

The energy that powers the earth's climate system comes from the sun. Climate changes caused by variations in the composition and intensity of incident solar radiation hitting the Earth may be distinct from and complementary to those caused by man-made climate change on a global and regional scale. Solar variation appears to have a significant impact on regional climate in the current time. Row spacing has a significant impact on canopy temperature and crop radiation absorption. When row spacing is increased, the crop's ability to absorb radiation declines, more radiation falls on the soil surface, and the soil temperature rises. If row spacing is reduced, however, radiation interception by the crop increases and transmission to the soil surface decreases, lowering soil temperature. The cumulative effect of more effective tillers per unit area, grain number per spike, and grain weight amounted to a significantly higher grain yield in the N-S row direction. Lower canopy temperature and higher incidence of light in the upper canopy as the crop matured may have aided photosynthetic in the grain fill stage, resulting in increased grain yield. Planting the crop on N-E side of the ridge also reduce the solar load in crop plant by avoiding the direct sunrays.

\section{Modification of Precipitation through artificial rain making}

Short-term crop failures and longterm production let-downs are more likely as precipitation patterns change. Erratic rainfall with a high $\mathrm{CV} \%$ result in erosion and water logging. Over the last 100 years, a trend of increasing monsoon seasonal rainfall has been observed along the west coast, norther Andhra Pradesh, and northwestern India $(+10$ to $+12 \%)$, while a trend of decreasing monsoon seasonal rainfall has been observed over eastern, north-eastern India, and parts of Gujrat and Kerala (-6 to $7 \%)^{[44]}$. The most important requirement of a crop is moisture. Rainfall is critical in rainfed crops. The amount and distribution of rainfall throughout the crop's life cycle determines its growth. Moisture deficiency is harmful at any stage of the crop's life cycle, but it is especially lethal during the reproductive period. To mitigate the effects of a moisture deficit, artificial rain can be used. Because there may not be enough condensation nuclei in the atmosphere, artificial rain is based on the principle of introducing artificial condensation nuclei into clouds. This is referred to as weather modification. In 1930, Bergeron and 
Findeicen proposed a theory that rain drops form in clouds when a few ice crystals appear at temperatures below $0^{\circ} \mathrm{C}{ }^{[1]}$. After that cloud seeding is being popularised. Cloud seeding is a methodology for altering the weather. Artificial rain is created in this process by spraying dry ice or silver iodide aerosols into the upper part of the cloud in an attempt to stimulate precipitation and form rain. Aeroplanes and rockets can be used to stimulate the brain. Silver iodide is the most commonly used substance because it is inexpensive and readily available. The types of cloud seeding methods are as follows:

$>$ Hygroscopic cloud seeding: In this method, the salts are dispersed in the lower part of the clouds using flares or explosives. When salt molecules come into contact with water, they grow in size.

$>$ Static cloud seeding entails spraying a chemical such as silver iodide into the air or cloud. Silver iodide forms a crystal around it, allowing moisture to condense.

$>$ Dynamic cloud seeding: This technique boosts the vertical air current, allowing more water to pass through the clouds droplets, and they multiply quickly. They fall in the form of rain, hail, or snow from the sky.

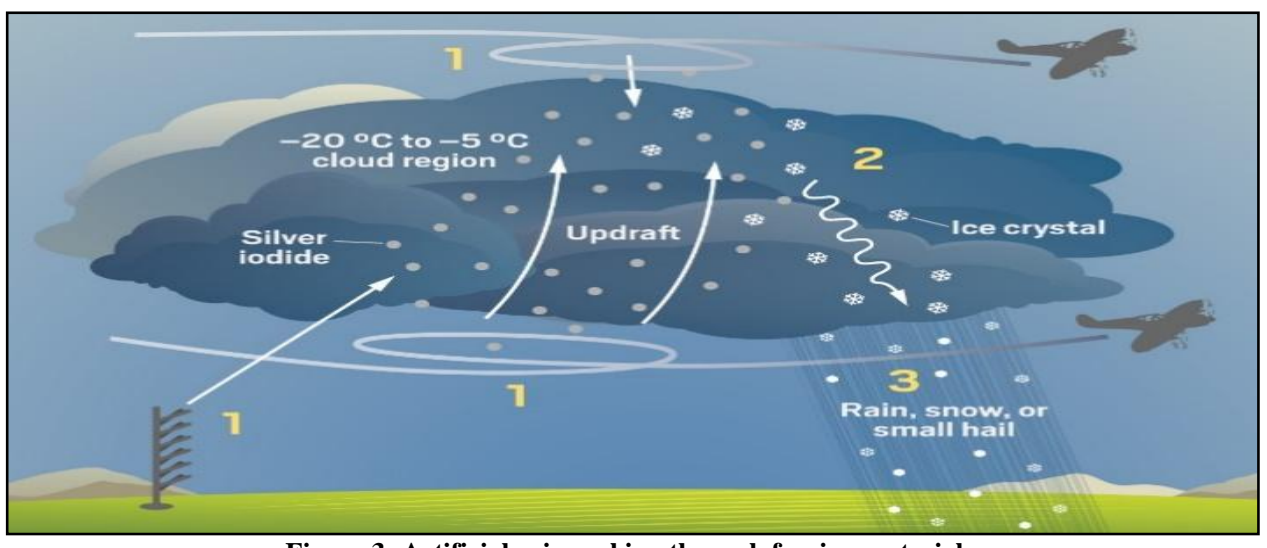

Figure 3: Artificial rain making through foreign materials

(source: https://www.google.com/url?sa=i\&url=https\%3A\%2F\%2Fm.nguoiduatin.vn )

Modification of wind through windbreaks and shelterbelts

"There is evidence for long-term changes in the large-scale atmospheric circulation, such as a poleward shift and strengthening of the westerly winds," according to the Intergovernmental Panel on Climate Change, and these changes are likely to continue. Windbreaks are a row or a group of trees, shrubs or structural elements used to block and direct the wind (e.g., fences). Windbreak trees protect a field from prevailing wind patterns, reducing wind speed significantly before it reaches the crops. By limiting wind speed, windbreaks alter the climate in the areas they cover. Reduced wind speed has a variety of consequences, including moderated soil and air temperatures, increased relative humidity, reduced evaporation and increased soil moisture, and changes in snow distribution. The temperature behind the shelterbelt is usually slightly higher because the wind's cooling influence is no longer there. Reduced wind exposure and increased humidity lower soil and crop evapotranspiration rates, allowing for more effective water use. Reduced kinetic impacts from wind, such as crop leaf damage and top soil erosion, is another good effect. As with other agroforestry practises, increasing water demand from windbreak trees is a significant problem. Windbreaks protect buildings from winter wind and summer sun, saving energy and lowering heating and cooling costs. Windbreaks can save up to $25 \%$ on winter heating expenditures. Windbreaks can save you a lot of money on air conditioning in the summer. 


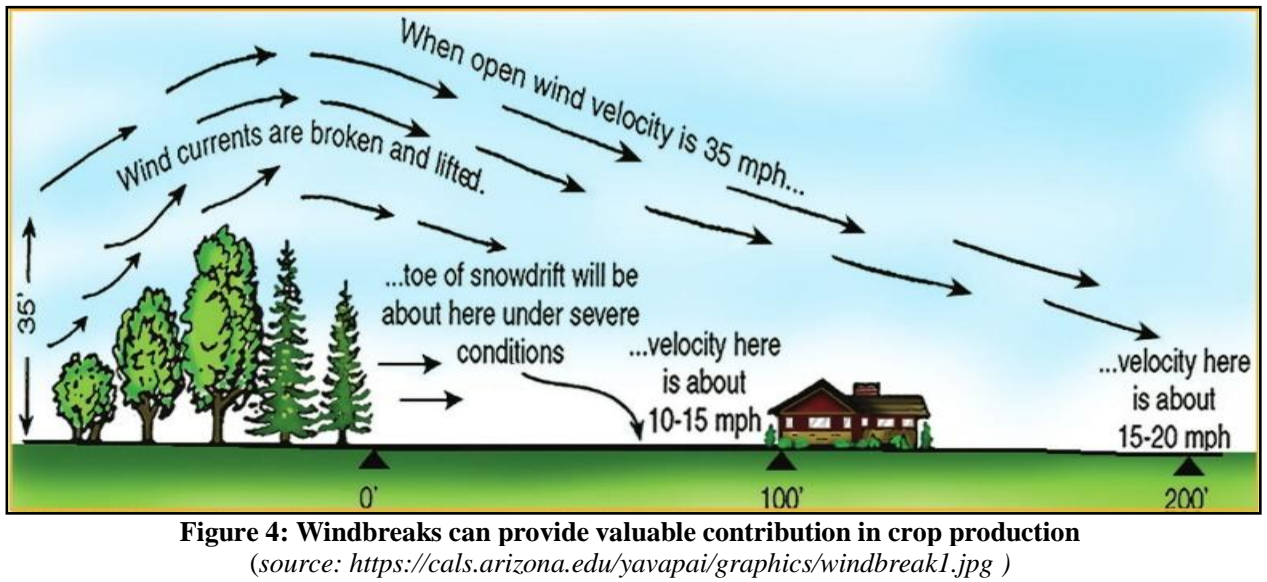

\section{Modification of plant growth through Fertilizer management}

Crop nutrients, whether organic or mineral, are the foods that nourish the plants, which in turn nourish the people. As a result, fertilisers are essential for food security. Damage due to frost is more occurred in unhealthy crops, and fertilisation improves plant health. Fertilization with nitrogen prior to a frost, on the other hand, promotes growth but increasing susceptibility to frost damage. To improve plant hardening, avoid using too much nitrogen fertiliser. Nitrogen fertilisation, on the other hand, gives the crop a new flush of growth after waterlogged situation. Phosphorus which is essential for cell division and tissue development be a boon after freezing injury. Phosphorus also helps in drought situation by improving the leaf water content, photosynthesis rate. Potassium has a positive effect on plant water regulation and photosynthesis. Some encouraging results have recently been obtained with postflowering foliar application of various nutrients on wheat yield. It was reported that spraying $0.5 \% \quad \mathrm{KNO}_{3}$ at $50 \%$ flowering stage of the crop resulted in higher grain and straw yield ${ }^{[7]}$. Nowadays one of the reasons for crop yield reduction is a lack of micronutrients. Zinc is one of the micronutrients that plays an important role in most plants' metabolic activities. Zinc spraying in drought conditions increases the number of grains per spike, grain weight, and harvest index when compared to no spraying.

\section{Modification of Cyclone through cloud seeding}

Warmer sea surface temperatures (above $26.5^{\circ} \mathrm{c}$ ) may increase the speed of tropical storm winds, causing more damage if they make landfall. Cyclones are one of the most dangerous weather hazards, wreaking havoc on agricultural crops in coastal areas. Cyclones have a negative impact on all human activities. These cyclones are also known as tropical cyclones, typhoons, or hurricanes. The main benefit of these cyclones is that they cause rainfall over land in dry areas, but excessive rainfall can cause flooding over a large area, especially near the coast. Because of the devastation caused by these weather systems, they must be modified. Cyclones can be modified by seeding the outer clouds surrounding the eye of the cyclone so that precipitation occurs before the mature stage is reached. An enormous amount of latent heat of condensation is released during precipitation. The latent heat has the tendency to disperse the storm over a large area, reducing the impact of violent force. Because the cloud surrounding the eye of the cyclone contains a large amount of super cooled water with temperatures below $-4^{\circ} \mathrm{C}$, silver iodide is used as a seeding agent. It is based on the principle that the vapour pressure of ice crystals is less than that of supercooled water droplets. As a result, ice crystals form at the expense of droplets. The 
addition of silver iodide can turn supercooled water droplets into ice crystals. The latent heat of fusion is released during this process. It has the ability to disperse the cyclone in such a way that the magnitude of the violent force is reduced.

\section{Modification of frost through heaters, fire and smoke}

Frost is the ice coating or deposit that can generate, usually overnight, in wet air under cold conditions. This happens when the Earth's surface temperature and any earth-bound object drops below zero degrees (freezing). For centuries, fire and smoke have been used in traditional agricultural systems. Heaters provide additional heat to compensate for energy losses. Heaters, in general, either raise the temperature of metal objects (e.g., stack heaters) or function as open fires. If enough heat is added to the crop volume to compensate for all energy losses, the temperature will not drop to dangerous levels. They are cost effective for high value crops (sugarcane, coffee, tea etc). Biomass residues (crop straw, residue, waste etc) are also used to heat the crop environment in windy condition. Straw burning in the wind creates a smoke layer over the crop surface that absorbs long-wave radiation released by the soil, protecting the mustard crop from frost by boosting the ambient temperature. Smoke particles are typically less than $1 \mu \mathrm{m}$ in diameter, reflect visible light but are impervious to long wave radiation, and hence prevent rapid cooling of the ground surface ${ }^{[30]}$. In frost time even light watering or sprinkling helps in frost protection by releases latent heat and prevents the tissues of the plants it coats from freezing. Sprinkler irrigation provides good frost protection and raises the temperature of the microclimate. Sprinkler irrigation increases long-wave radiation and sensible heat transmission to the plants when compared to an unprotected crop. By wetting the soil, it becomes darkens, which increases the absorption of solar radiation and avoid the chilling injury. Using powerful blowers to reduce wind, preventing the formation of cold air accumulations, Crop covering or wrapping (high-value crops), Heat to keep the temperature from dropping too quickly, Smoke production to reduce radiation cooling are Some other Typical measures to prevent frost or reduce its severity.

\section{Modification of heat waves through Protected cultivation}

Heatwaves, or prolonged hot weather periods, can have significant social effects including higher deaths due to hot weather. Temperatures of days and nights are becoming more as climate change becomes more common. Increases in extreme heat events may result in an increase in heat-related illnesses and deaths, resulting in decreased productivity and lower-quality produce. Protected cultivation makes it possible to obtain increased crop productivity by maintaining a favourable environment for the plants by reducing the heat waves. The use of netting and other type of covering has been shown to restrict air movement around the growing seedlings in higher temperature [26]. Protected cultivation, on the other hand, is used to protect plants from harsh climatic conditions by providing optimal lighting, temperature, humidity, $\mathrm{CO}_{2}$, and air circulation for optimal plant growth and quality. Increased air temperatures inside the house combined with improved moisture status and root development, increased nutrient uptake, favouring leaf conductance and chlorophyll content.

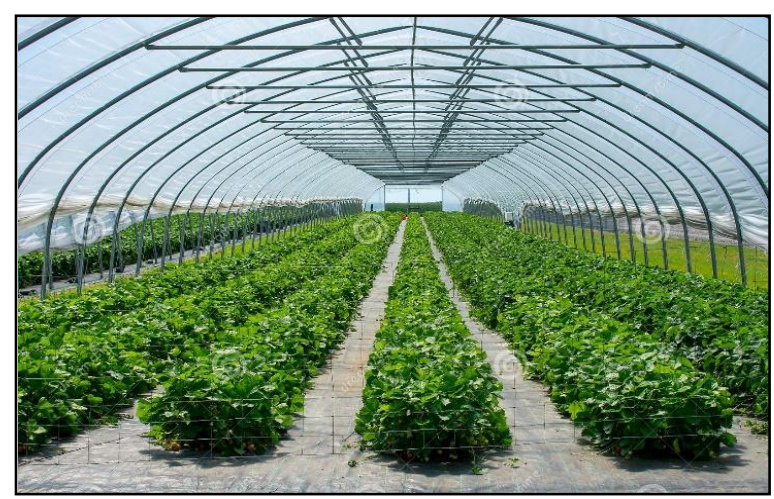

Figure 5: Growing crops in greenhouse as protected cultivation

(source: https://thumbs.dreamstime.com/z/strawberries-protectedcultivation ) 


\section{Modification of flood through dam, and land-form change}

As a consequence of climate change, floods and droughts have become more frequent, posing a threat to traditional irrigation design and management systems. Construction of dams and detention basins can help to reduce flood peaks. Dams can hold a large amount of water during a flood and help to reduce the peak volume of water during a flood. Depending on the accommodating capacity of the river downstream of the dam, water stored in reservoirs created by dam construction can be allowed to flow down the stream under controlled conditions. These dams have aided in the reduction of flood peaks in downstream areas. Ponds, tanks, and surface storage structures, in addition to dams, help with flood control and water harvesting during dry seasons. Raised Beds are a revolutionary way to prevent water logging that increases productivity significantly. Permanent Raised beds and broad beds, are the land modification that helps to save 25$35 \%$ of irrigation water, improve water efficiency, and avoid excess water near the crop root zone.

\section{CONCLUSION}

Microclimatic modifications help to adjust the unfavourable conditions prevalent in the vicinity of the plants, allowing for greater crop growth and development, yield in the current situation of global warming and increased occurrence of extreme weather events. These Field level modifications of the physical environment, such as solar radiation, soil temperature, soil moisture, and wind speed, among other things, at the farm level have proven to be extremely beneficial for improved crop growth and yield performance. According to this study, the intensity and frequency of extreme weather elements are likely to increase in the future, and microclimatic modifications can be a very effective adaptation measure for managing extreme weather vulnerability and climatic risks in crop production to ensure food security and natural resource sustainability in the future.

Acknowledgement: None

Conflict of Interest: None

Source of Funding: None

\section{REFERENCES}

1. AILSA ALLABY and MICHAEL ALLABY "Bergeron theory." A Dictionary of Earth Sciences. Retrieved August 16, 2021 from Encyclopedia.com: https://www.encyclopedia.com/science/dicti onaries-thesauruses-pictures-and-press releases/bergeron-theory

2. Agam, N., \& P.R. Berliner (2006) Dew formation and water vapor adsorption in semi-arid environments; a review. Journal of Arid Environments. Vol. 65, Issue 4, June 2006: 572-590;

3. Aggarwal, P.K. 2008. Global climate change and Indian agriculture: impacts, adaptation and mitigation, Indian Journal of Agricultural Sciences 78: 911-919

4. Bonan, G. (2016) Ecological Climatology; Concepts and Applications. 3rd Edition. Boulder: University of Colorado;

5. Bot, A. \& J. Benites (2005a) Droughtresistant soils; optimization of soil moisture for sustainable plant production. FAO Land and Water Bulletin 11. Rome;

6. Britannica, The Editors of Encyclopaedia. "Microclimate". Encyclopaedia Britannica, 19 Mar. 2020, https://www.britannica.com/ science/microclimate. Accessed 24 August 2021.

7. Das, S. and Sarkar, A. K., 1981, "Effect of post-flowering foliar spray of potassium nitrate solution on grain filling and yield of rice and wheat", Indian Agric., 25, 267-273.

8. Deng, X.P., Shan, L., Zhang, H.P. and Turner, N.C. 2006. Improving agricultural water use efficiency in and semiarid areas of China, Agricultural Water Management 80: 23-40.

9. FAO (2016) Physical factors affecting soil organisms. Cited from the World Wide Web at:

http://www.fao.org/agriculture/crops/themat ic-sitemap/theme/spi/soil-biodiversity/soil organisms/physical-factorsaffecting-soilorganisms/en/ 
10. Ferris, R., Ellis, R. H., Wheeler, T. R. and Hadley, P., 1998, "Effect oHigh Temperature Stress at Anthesis on Grain Yield and Biomass of Field-grown Crops of Wheat", Ann. Bot.-London, 82, 631-639.

11. Fischer, G., Tubiello, F. N., Velthuizen, H. V. and Wiberg, D. A., 2007, "Climate change impacts on irrigation water requirements: effects of mitigation, 19902080", Technol. Forecasting Soc. Change, 74, 1083-1107.

12. Foken, T. (2008) Micrometeorology. Berlin Heidelberg: Springer-Verlag;

13. Fritton, D. D. and Martsof, J. D., 1981, "Solar energy, soil management and frost protection", Hort. Sci., 16, 295-296.

14. Gliessman, S.R. (2015) Agroecology; the ecology of sustainable food systems. 3rd edition. Taylor \& Francis Group;

15. IPCC 2014. Climate change Impacts, adaptation and vulnerability, Working group II contribution to the fifth assessment report of the Intergovernmental Panel on Climate Change. Technical report. Cambridge University Press, Cambridge, UK/New York, USA.

16. IPCC 2007. Summary for Policymakers, In: Climate Change 2007: Mitigation. Contribution of Working Group III to the Fourth Assessment Report of the Intergovernmental Panel on Climate Change, Cambridge University Press.

17. Iqbal, M., Hassan, A.U. and Ibrahim, M. 2008. Effects of tillage systems and mulch on soil physical quality parameters and maize (Zea mays L.) yield in semi-arid Pakistan. Biological Agriculture and Horticulture 25: 311-32.

18. International Water Management InstituteIWMI (2015) Sustaining the Benefits of Soil and Water Conservation in the Highlands of Ethiopia. Research Program on Water, Land and Ecosystems, Technical Brief. December 2015;

19. Jalota, S.K., Khera, R., Arora, V.K. and Beri, V. 2007. Benefits of straw mulching in crop production: a review, Journal of Research 44: 104-107.

20. Jackson, R.B., J.T. Randerson, J.G. Canadell, R.G. Anderson, R. Avissar, D.D. Baldocchi, G.B. Bonan, K. Caldeira, N.S. Diffenbaugh, C.B. Field, B.A. Hungate, E.G. Jobbágy, L.M. Kueppers, M.D. Nosetto \& D.E. Pataki (2008) Protecting climate with forests. Environmental Research Letters 3 (2008): 044006

21. Jha, S., Sehgal, V.K. and Subbarao, Y.V. 2012. Effect of direction of sowing and crop phenotype on radiation interception, use efficiency, growth and productivity of mustard, Journal of Agricultural Physics 12: $37-43$

22. Kar, G. and Kumar, A. 2007. Effects of irrigation and straw mulch on water use and tuber yield of potato in eastern India, Agricultural and Water Management 94: 109-116.

23. Katsoulas, N. and Kittas, C. 2008. Impact of greenhouse microclimate on plant growth and development with special reference to the solanaceae, The European Journal of Plant Science and Biotechnology 2 (Special Issue-1): 31-44.

24. Kaur, A., Dhaliwal, L.K. and Singh, S. 2014. Microclimatic variations under different planting methods of rice, Oryza sativa L., International Journal of Farm Sciences 4: 24-32.

25. Kees stigter, kulasekaran ramesh and pravin kumar upadhyay. Mulching for microclimate modifications in farming-An overview University of the Free State, Bloemfontein, South Africa 9300 August 2018

26. Majumder, A. 2010. Large-scale net house for vegetable production: Pest management success and challenges for a new technology, Alabame Coop. Ext-System, Auburn Univ., Auburn AL

27. Mahi, G.S. and Kingra, P.K. 2013. Comprehensive Agrometeorology, Kalyani Publishers. pp 355.

28. Marcott et al, A Reconstruction of Regional and Global Temperature for the Past 11,300 Years, Science vol. 339, pp. 1198. 2013.

29. Meehl, G.A., Stocker, T.F., Collins, W.D., Gaye, A.J., Gregory, J.M., Kitoh, A., Knutti, R., Murphy, J.M., Noda, A., Raper, S.C.B., Watterson, J.G., Weaver, A.J. and Zhao, Z. 2007. "Global Climate Projections", In: Solomon, S., Qin, D., Manning, M., Chen, Z., Marquis, M., Averyt, K. B., Tignor, M. and Miller, H. L. (Eds.), Cambridge University Press, Cambridge, U.K. and New York, NY

30. Mee, T. R. and Barthilic, J. R., 1979, "Manmade fog. Modification of the aerials Environment of plants", (Barfield, B. J. and 
Gerber, J. F. eds.), Am. Soc. Agric. Engin. Monograph., 2, 334-352

31. Nicholson, S.E. (2012) Dryland Climatology. Cambridge: Florida State University;

32. Ong, C.K., C.R. Black \& J. Wilson (eds.) (2015) Tree-crop interactions: agroforestry in a changing climate. Second Edition. Wallingford, Oxfordshire. UK; Boston, MA, USA: CAB International

33. Richards, K. (2004) Observation and simulation of dew in rural and urban environments. Progress in Physical Geography, 28 (2004): 76-94.

34. Rawls, W.J., Y.A. Pachepsky, J.C. Ritchie, T.M. Sobeckic \& H. Bloodworth (2003) Effect of soil organic carbon on soil water retention. Geoderma. Vol.116: 61-76;

35. Ramesh, K. 2010. A more efficient use of agricultural inputs as part of adoption of preparedness strategies: multiple cropping. Section III.3.1. (d) (In) Applied Agrometeorology, pp. 435-440. Stigter, K. (Ed.). Springer, Berlin/Heidelberg etc.

36. Sai, M.V.R.S., Murthy, C.S., Chadrasekar, K., Jeyaseelan, A.T., Diwakar, P.G. and Dadhwal, V.K. 2016. Agricultural drought: Assessment \& monitoring, Mausam 67: 131-142.

37. Stigter, C.J. 1994a. Management and manipulation of microclimate. Handbook of Agricultural Meteorology, pp. 273-284. Griffiths, J.F. (Ed.). Oxford University Press.

38. Stigter, C.J. 1994b. Micrometeorology. (In) Handbook of Agricultural Meteorology, pp. 59-72. J.F. Griffiths (Ed.). Oxford University Press

39. Seneviratne, S.I., T. Corti, E.L. Davin, M. Hirschi, E.B. Jaeger, I. Lehner, B. Orlowsky \& A.J. Teuling (2010) Investigating soil moisture-climate interactions in a changing climate: a review. Earth-Science Reviews. Vol. 99. Issue 3-4, May 2010: 125-161;

40. Semenzato, R., M. Falciai, E. Bresci (1998) The Project "Fog as a new water resource for the sustainable development of the ecosystems of the Peruvian and Chilean coastal desert". In: First International Conference on Fog and fog collection, Vancouver (Canada), 19-24July 1998: 457460 ;

41. Seneviratne, S.I., T. Corti, E.L. Davin, M. Hirschi, E.B. Jaeger, I. Lehner, B. Orlowsky \& A.J. Teuling (2010) Investigating soil moisture-climate interactions in a changing climate: a review. Earth-Science Reviews. Vol. 99. Issue 3-4, May 2010: 125-161;

42. Shaxson, F. \& R. Barber (2003) Optimizing soil moisture for plant production: the significance of soil porosity. Rome: Food and Agriculture Organisation of the United Nations. FAO Soils Bulletin 79;

43. Steenbergen, F. van, A. Tuinhof \& L. Knoop (2011) Transforming Landscapes, Transforming Lives. The business of sustainable water buffer management. Wageningen, the Netherlands: 3R Water Secretariat; Stigter, K. (ed.) (2010) Applied agrometeorology. Springer;

44. Sr Reddy., Principles of Agronomy, pp. 244-300. 2019.

45. Tomaszkiewicz, M., M. Abou Najm, I. Alameddine \& M. El Fadel (2014) Dew as an adaptation measure to meet agricultural and reforestation water demand in a changing climate. Agricultural and Forest Meteorology vol. 16 (2014): 11625;

46. Walker, B. \& D. Salt (2006) Resilience Thinking: Sustaining ecosystems and people in a changing world. Washington/Covelo/ London: Island Press.

47. Wang, Z., Li, S., Cecil Vera, L. and Sukhdev Malhi, S., 2005, "Effects of water deficit and supplemental irrigation on winter wheat growth, grain yield and quality, nutrient uptake, and residual mineral nitrogen in soil", Soil Sci. Plant Analysis, $36,11,1405-1419$.

How to cite this article: Debangshi U. Crop microclimate modification to address climate change. International Journal of Research and Review. 2021; 8(9): 384-395. DOI: https:// doi.org/10.52403/ijrr.20210950 